症 例

抗カルシウム剤と Blood Potassium Cardioplegia に よる心筋保護法

信州大学第 2 外科教室（主任：飯田 太教授）

$\begin{array}{lllllllll}\text { 森 } & \text { 本 } & \text { 雅 } & \text { 巳 } & \text { 志 } & \text { 田 } & \text { 寛 } & \text { 井之川 } & \text { 一 } \\ \text { 津 } & \text { 金 } & \text { 次 } & \text { 郎 } & \text { 杠 } & \text { 英 } & \text { 樹 } & & \end{array}$

\title{
MYOCARDIAL PROTECTION BY CALCIUM ANTAGONIST (DILAZEP) AND BLOOD POTASSIUM CARDIOPLEGIA
}

Masami MORIMOTO, Hiroshi SHIDA, Koichi INOKAWA, Jiro TSUGANE and Hideki YUZURIHA

The Second Department of Surgery, Shinshu University School of Medicine

(Director : Prof. Futoshi Iida)

優れた心筇保護法とは大動脈遮断中，良好な心筋保護を行うとともに血流再開時の Reperfusion Injury を防止することであろう。この観点より心筋保護についての実験が 行われ，その実験成䋶から現在われわれが施行している独自の心筋保護法が考案された。 今回この実験の概略と本心筋保蒦法を施行した開心術例について臨床的検討を加えたの でその成績を報告する. 実験：雑種成犬の摘出左室心筋潅流標本について, (1)薬物の冠 動脈注入による myocardial contractility および心筋内カルシウム含有の湘定, (2)阻血 前後の isometric tension を比較し，その\% recovery rate を心機能回復の指標とする実 験で，各種薬物を注入し，心筋保護効果を判定する方法において，(1) Dilazep が抗カル シウム作用を示し, (2) Dilazep 前処置に Young 液を冠潅流することが, ほかの薬物と比 较して心筋保護効果が有意に認められた。臨床的検討：実験より次の心筋保護法を臨床 に応用した. 方法：Dilazep (300mg/日)を䄪10日間経口投与し，大動脈遮断後Young 液による急速心停止および ice slushによる心表面冷却を行う. 次に Blood Potassium Cardioplegia 液（10\%マルトース液 $200 \mathrm{ml}+$ ハ・リン血 $200 \mathrm{ml}, \mathrm{K} 28.5 \mathrm{mEq} / \mathrm{L}) 5 \mathrm{ml} / \mathrm{kg}$ を冷却して間歇的 (30分每) に落差冠潅流を行 万方法である. 対象：後天性心疾患34例， 先天性心疾患14例など計49例。これらの症例につき, 手術成䋶, CPK-MB の変動, 左心 室機能の推移などを検討し，ほぼ満足すべき成樍を得た。すなわち，抗カルシゥム成 (Dilazep) と Blood Potassium Cardioplegiaによる心筋保護法は臨床的に満足される むのと考えられる.

\section{I. 緒 豆}

開心術中, 大動脈遮断時の心筋保護法は Shumway ら”の報告以来, 多数の方法, 成果などが発表されてい、 る。われわれも，従来より心表面冷却を基本にして， Young 液による心停止を併用する方法および领却血 液による間歇的冠潅流を併用する方法を行ってきた。
その後, 実験で各種薬物の心筋保讙効果を検討したと ころ, 特に Dilazep に心筋保護効果のあることが諗め られ，またDilazepが抗カルシゥム作用を有すること より，最近はわれわれ独自の方法，すなわら，術前に Dilazep の経口投与を行い, Young 液による心停止お よび心表面冷却，これらに間歇的 Blood Potassium 
Cardioplegia を追加する心筋保護法を行っている. 今 回，実験成耫とともに本法を施行した開心術症例につ いて臨床的検討を行ったので報告する。

\section{II. 実験的検討}

実験方法および実験成績の詳細は既に Shida $ら^{21} に$ より報告されているが，実験方法は図 1 のごとく， Chiba ${ }^{3)}$ 方法に従った雑種成犬の摘出左室心筋冠潅 流標本を用い, 薬物を冠状動脈に注入して myocardial contractilityにおよばす効果をみるもので，心筋阻血 前後の isometric tension を比較し，その\% recovery rate を心機能回復の指標とする実験を行った．薬物の 心筋保護奻果および抗カルシゥム作用について検討し た.

\section{a) 各種菜物の心腰保護奻果について}

图 2 のIIIーVIIのごとき各種菜物を冠状動脈人直接， 注入潅流し， $37^{\circ} \mathrm{C}$ の心筋温で 45 分の阻血を行った。 I 群は対照で, $37^{\circ} \mathrm{C}$ の筋温で 45 分の阻血, II 群は心筋 冷却群で薬物は注入せず, $30^{\circ} \mathrm{C}$ の心筋温で 45 分の阻血 を行った、VII群の Dilazep ( $0.3 \mathrm{mg} / 15 \mathrm{ml}$ 生食)は心筋 冷却 $30^{\circ} \mathrm{C}$ と同様の心筋保讙奻果を示した.

b) Dilazep 前処固の心筋保護効果にっいて.

Support 犬に Dilazep $(0.3 \mathrm{mg} / \mathrm{kg})$ を静脈投与し, 心筇温 $37^{\circ} \mathrm{C} て ゙ ， 45$ 分の阻血を行ったところ\% recovery rateは対照と比較して有意の低下を示したが, Dilazep を同量静注後15分に Young 液を 2 分間潅流し，心 筋温37゚で45分の阻血を行った方法では\%Rは有意の 増加が虫められた（图 2 VIII).

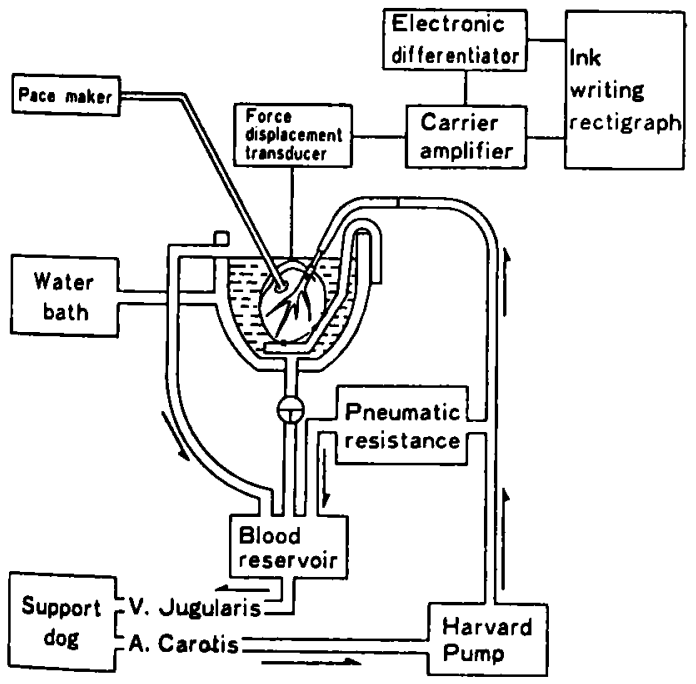

图 1

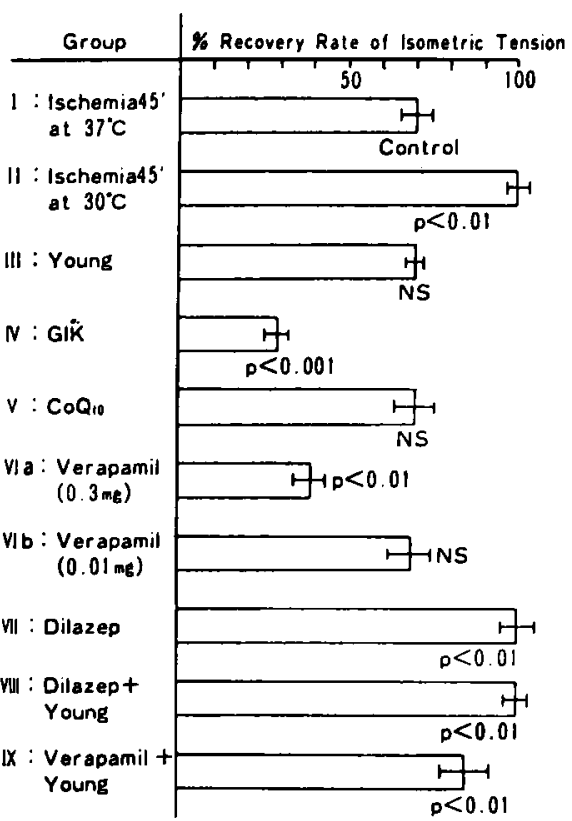

图 2

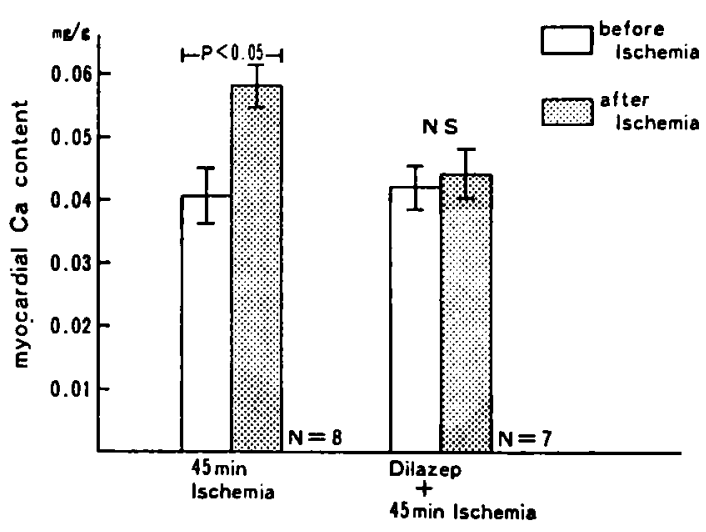

図 3

\section{c) Dilazep の抗カルシウム作用について}

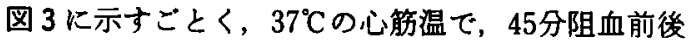
の心筋内カルシゥム含有を測定した。対照はI群で， 心筇内カルシゥム含有は再潅流後有意に増加したか; VI群では心筋内カルシゥム含有には有意の变動は諮め られなかった。 また, Dilazepの myocardial contractilityに及ぽす効果を検討したところ, Dilazepを冠状 動脈に注入すると, isometric tension は約 $50 \%$ に減少 し，前値に復するのに約20分を要した。

以上から Dilazep は抗カルシゥム作用を有し，それ 
Components

\begin{tabular}{lc} 
Blood (heparinized) & $200 \mathrm{~m} \ell$ \\
$10 \%$ Maltose & $200 \mathrm{~m} \ell$ \\
$\mathrm{KCl}$ & $10 \mathrm{mEq}$ \\
$7 \% \mathrm{NaHCO}_{3}$ & $30 \mathrm{~m} \ell$ \\
\hline $\mathrm{pH}: 7.8$ Osmorality $: 420 \mathrm{mOsm} / \mathrm{L}$ \\
$\mathrm{Na}: 113 \mathrm{mEq} / \mathrm{La}: 1.30 \mathrm{mEq} / \mathrm{L}$ \\
$\mathrm{K}: 28.5 \mathrm{mEq} / \mathrm{Ht}: 20 \%$
\end{tabular}

Method

Drip coronary perfusion
Flow rate: $200 \mathrm{~m} \ell / 5 \mathrm{~min}$
Intermittence: Interval
Cooling : ca. $10^{\circ} \mathrm{C}$

図 4

単独でも心筋保護効果を示すが，これを前処置した場 合には Young 夜を併用することにより心筋保護効果 を示すことが明らかとなった。

\section{III. 臨床的検討}

a ）心筋保護法

〔1]の実験成績より, 次の心筋保護法を開心術に施 行した.すなおち，(1)術前にDilazep（300mg/日）の 経口投与を的10日間行5。(2)大動脈遮断後 Young 液 (pH 7.8)を冠潅流し，急速心停止を行5. (3) ice slush による心表面冷却を大動脈遮断中行 5. (4) Blood Potassium Cardioplegia（BPC）を間歇的に冠潅流す る。その組成はへパリン血 $(200 \mathrm{ml}) を 10 \%$ マトース 液 $(200 \mathrm{ml})$ で希釈したもので，これにカリウム $10 \mathrm{mEq}$ を加之， $\mathrm{pH} 7.8$ に調整し，浸透王は $420 \mathrm{mOsm} / \mathrm{L}$ 前後 とした。この溶液中の電解質などは図 4 のごとくであ る. 冠潅流方法は落差による30分毎の間歇的潅流であ Ђ.

\section{b）对象および方法}

本法を施行した開心術症例は大動脈并置換術12例, 僧帽弁置換術16例，僧帽弁交連切開術 6 例，先天性心 疾患14例怙よび左房粘液腫 1 例，計49例である。各術 式の大動脈遮断時間（平均時間）は表 1 のごとくであ る.なお，大動脈遮断時間60分末满は11例，120分末满 29例, 180 分末満 9 例で, 最長遮断時間は155分である. これらの症例について手術成績, creatinin phospho-
表 1

\begin{tabular}{c|c|c}
\hline \multicolumn{1}{c|}{ Procedure } & $\begin{array}{l}\text { No. of } \\
\text { cases }\end{array}$ & $\begin{array}{c}\text { Aortic cross- clamp } \\
\text { time (min.) }\end{array}$ \\
\hline AVR + OMC \\
MVP & 12 & $87 \sim 155$ (mean 120.9) \\
\hline MVR + $\begin{array}{c}\text { TAP } \\
\text { AVP }\end{array}$ & 16 & $67 \sim 136(89.4)$ \\
\hline OMC (MVP) & 6 & $45 \sim 112(74.2)$ \\
\hline Repair of C.H.D & 14 & $35 \sim 146(67.4)$ \\
\hline $\begin{array}{l}\text { Excision of } \\
\text { myxoma }\end{array}$ & 1 & 73 \\
\hline \multicolumn{1}{c|}{ Total } & 49 & \\
\hline
\end{tabular}

kinase (CPK) 括よび CPK-MB の変動, 左心室機能の 推移および本法とほかの心筋保護法との成綪の比校な どを検討した、CPKはジャチール・オルチノール法， CPK-MB はカラム法で湘定した。検査時点は手術直 前, 術後 3 時間, 術後24時間および術後48時間である。 左心室機能は手術直前および大動脈遮断解除後 2 時間 に日本光電製微分演算ユニット（EQ-600）を用いて， maximum contractile element velocity $(\mathrm{Vpm}) お$ び $\max \mathrm{dp} / \mathrm{dt}$ を測定した.

c) 成績

（1）手術成繶

本法を施行した開心術应例49例の術中，衍後の成續 を述べると，心筋温は $15.7 \pm 3.7^{\circ} \mathrm{C}$ ，大動脈遮断後すな わち開心術終了後の部分体外循環（補助循環）時間は $26.7 \pm 8.4$ 分, 電気的除細動の非施行例あるいは 1 回范 行例は31例（63\%）であった，開心術終了後，少典あ るいは短時間でも inotropic agents を投与した症例は 18例（36\%）であった．本法に起因する不整脈の発生， 体外㨁環離脱不能例は認められず, いわゆる Reperfusion injury を示したと思われる症例はない，死亡は3 例に認められたが，本法による心筋保護法を原因とし ないものである.

\section{（2）CPK および CPK-MB の变蚛}

表 2 に示した時点で测定し，それぞれの変動をみる と, CPK は術後24時間で最高値を示すが, CPK.MB は 術後 3 時間で有意 $(p<0.001)$ の最高値を示し, 㭪绻 48時間には正常に復した。

\section{（3）左心室機能の推移}

術前たよび術直後の Vpm, max dp/dt を測定して, 本法の心筋保護効果を検討した。対象を大動脈遮断時 間の60分末満と60分以上に分けてみると，術前・㭪直 後の V pm, max dp/dt は表 3 に示すごとく，二群とも 
Changes in Serum CPK and CPK-MB

\begin{tabular}{l|c|c|c|c}
\hline & pre- op. & postop. 3 hrs & $24 \mathrm{hrs}$ & $48 \mathrm{hrs}$ \\
\hline CPK (mlU) & $174 \pm 157$ & $1280 \pm 645$ & $1613 \pm 996$ & $1268 \pm 881$ \\
\hline CPK-MB (\%) & $4.1 \pm 2.6$ & $10.4 \pm 4.5$ & $6.9 \pm 4.7$ & $4.1 \pm 2.3$ \\
\hline
\end{tabular}

表 3 Left ventricular Function

\begin{tabular}{l|c|c|c|c}
\hline \multirow{2}{*}{$\begin{array}{l}\text { Period of } \\
\text { aortic clamp. }\end{array}$} & \multicolumn{2}{|c|}{ Vpm $\left(\mathrm{sec}^{-1}\right)$} & \multicolumn{2}{c}{$\max \mathrm{dp} / \mathrm{dt}(200 \mathrm{mmHg} / \mathrm{sec})$} \\
\cline { 2 - 5 } & Preop. & Postop. & Preop. & Postop. \\
\hline under 60 min. & $2.9 \pm 0.8$ & $2.7 \pm 0.5^{*}$ & $1600 \pm 600$ & $1660 \pm 450^{*}$ \\
\hline over 60min. & $2.5 \pm 0.9$ & $2.1 \pm 0.6^{*}$ & $1420 \pm 320$ & $1320 \pm 460^{*}$ \\
\hline
\end{tabular}

- : No Difference between Prop. and Postop. Values.

表 4 Results

\begin{tabular}{c|c|c|c|c|c|c|c}
\hline Group & $\begin{array}{c}\text { No. of } \\
\text { Cases }\end{array}$ & $\begin{array}{l}\text { Cross- clamp } \\
\text { time (min) }\end{array}$ & $\begin{array}{l}\text { M yocardial } \\
\text { tamperature } \\
\left({ }^{\circ} \mathrm{C}\right)\end{array}$ & $\begin{array}{l}\text { Rectal } \\
\text { temperature } \\
\left({ }^{\circ} \mathrm{C}\right)\end{array}$ & $\begin{array}{l}\text { Duration of } \\
\text { partial } \\
\text { perfusion } \\
(\mathrm{min})\end{array}$ & $\begin{array}{l}\text { Cases of } \\
\text { inotropic } \\
\text { support }\end{array}$ & Death \\
\hline I & 12 & $121 \pm 21$ & $15.6 \pm 3.6$ & $24.4 \pm 1.3$ & $32 \pm 6$ & $7(58 \%)$ & 1 \\
\hline II & 8 & $95 \pm 17$ & 21.0 & $28.3 \pm 1.0$ & $32 \pm 9$ & $1(12.5 \%)$ & 0 \\
\hline III & 10 & $149 \pm 46$ & $19.0 \pm 2.3$ & $27.5 \pm 1.6$ & $36 \pm 15$ & $7(70 \%)$ & 1 \\
\hline
\end{tabular}

に有意の推移は認められない。すなわち，本法は心筋 保讙効果のあることを示している.

（4）本法とほかの心觔保法との比較

本法=I 群(12例), Young 液による急速心停止と心 表面椧却法 =II群 (8 例) およびボンブによる間歇的 (30分毎)な 5 - 10分間の泠却回路血液冠潅流法＝【群 (10例) の方法で施行した主として大動脈弁置換術（I 群には連合弁疾患 5 例，III群には連合弁疾患 5 例およ びBentall 手術 2 例を含せ)を対象とした. 対象に差が あると考劣られ，明確な比较は困難と思われるが，表 4のごとき結果を得た。すなわら，I群では山群に比 整して良好な成綨が得られている。

\section{N. 考 莱}

近年，大動脈遮断時の心筋保萑法に咸する実験的な らびに臨床的研究が多方面上り数多く行われている. 著者の一人志田らは心筋保讙法の夷験的研究におい て，心㬳に影響する諸因子の集結された結果か心機能 であるとして，左心室機能を検討した。その評価とし $て$, 左心室心筋の myocardial contractility の測定を, Chiba ${ }^{3}$ の実験方法を用いて行った。この方法は心筋保 蕟効果の評価判定には充分に用いられるすのとされて
いる2)，最近の心筇保護法は心冷却ととすに真物を冠 潅流する方法が主として行われていることより，各種 薬物の心筋保讙奻果が検討された，実検に供された薬 物中, Dilazep に心筋保境効果があることが示され，実 匼（b）の方法で最す著明にその効果が恐められた，虚 血心筋に血流を再開した後，心筋損倿の出血がみられ ることい゙があり，いわゆる Reperfusion injury と呼ば れている.この心筇損信の発生にはカルシウムイオン が細胞内に異常蓄積していることが前提とされてい $\tau^{6)}$, この点から reperfusion injury 防止には抗カルシ ウム剤が有効とされている7. Dilazep は実跧 (c)に おいて抗カルシウム作用を有することが認められた。 すなわち，Reperfusion injury 防止の面からも Dila. zep は有効と考支られる.

$\operatorname{Dilazep}(1,4$-Bis- $\{3-(3,4,5$, -trimethoxy benzoyloxy）-propyl]-perhydro-1, 4-diazepine) は西独アス ター社により開発された冠扗張㓮阬で，その作用機序 としては血压および心拍に影锌を与えず, adenosine 増強作用により冠血流昷を增加させることが確認され ている。 また，阻血心筋に対する ATPならびにCP 蓄 箖作用などが判明しているが，本実鈋においても抗カ 
ルシウム作用があることが認められた。

この実験成績より臨床に応用出来る心筋保護法を考 案した。この方法について若干の説明を加えたい、は じめに, Dilazepの経口投与による前処置であるが，現 在 Dilazep の剂形が臨床では錠剂のみであるため, 経 口投与としなければならなかった。この方法は実験と は異なるすのであり，また Dilazep の経口投与による 実験成績は得られていないか，Dilazepの静注の前処 置と同じ効果と考え，やむを得ず行っている．今後， 経静脈投与が可能となれば実験方法に従って行ら方針 である。，心冷却の阻血に対する保護効果は Shumway ら”の報告以来広く認められている. その後, 種々の cardioplegic agents が研究され，それらの効果が立証 されているがこれらを臨床応用するに際しては，心 冾却あるいは全身低体温などの併用が行われ，安全性 を加えることが必要と考えられ，当然，われわれる局 所および全身の冾却を行っている. Nelson らのむ心冷 却および心筋保護液の単独施行よりも両者の併用が心 笳保護作用が認められたと述べている。

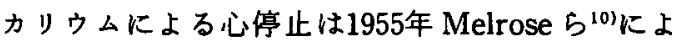
り無血静止野を得るため, たた空気塞栓防止のため, 心䁍手術に使用されたが，Young ${ }^{11}$ は0.5\% Potassium, 2.47\% Magnesium sulfate および Prostigmine よりなる夜を心筋保荄のために応用した，本実験成績 においてはYoung 液は $37^{\circ} \mathrm{C}$ 常温下では対照と比較し て心筋保護効果は認められなかった。しかし，Young 液による急速心停止は心泠却の併用により心筋高エネ ルギー燐酸化合物の温存および酸性代謝産物の抑制な どが助長されるものと考えられる。本実験では阻血時 間を45分として行われている. 臨床においては45分以 上の大動脈遮断を要する症例では追加の心筋保護が必 要と考えられた。このことよりカリウムを主体とした 組成の保護液および落差冠潅流による間歇的心筋保護 法を考案した。この追加心筋保護法は実験成績により 定めたものではないが，GIK 液が本実験においては心 筋保護効果の認められなかったことから10\%マルトー ス法が用いられた。一般にグルコースの阻血心筋に対 する作用は不明のよ5であるが， マルトースは等量で クルコースの 2 倍のカロリーを有し，インスリンを必 要とせず細胞内に入り，クルコースとなって代謝され ることから保護液の溶液とした。

心筋保讙に対する cardioplegiaの伝達手段として 血液を用いたのは Melrose ら ${ }^{101}$ が初めてであるが，最 近では, BPCが阻血心停止あるいは連続冠潅流よりる
心筋保讙に有奻である2)3)また BPCは crystalloid potassium cardioplegia よりも心筋保讙に優れている(4) などとされていることより，われわれの心筋保讙液を

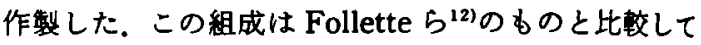

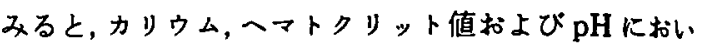
ては，ほぼ同じであるが，唚透圧およびカルシウムは われわれの BPCでは高値を示している．方法は臨床 に用いられるには簡便であることが要求される. BPC では血液供給源としてわれわれの方法および体外偱㻓 回路より導く方法があり，保護液潅流方法には落差に よるあのおよびボンプを用いて行うものがあるが, わ れわれは最す簡便と思われるパック採血したへバリン 血を基にした BPCの落差による潅流法を採用した。 間歇的潅流法は Takamoto ら“のの報告にるみられる が，心筋保護には有効な方法とされている。

本法を施行した開心術の成績はほぼ満足すべきすの と考えられる.すなわち，手術成績については，死亡 は3 例に認められたが，これらは大動脈弁置換術後の 溶血による腎不全の 1 例，はかの 2 例は僧帽并置換術 後扣よび心房中隔欠損症術後の肺合併症によるものて あり，本法施行を因としてはなかった。 ま, CPK-MB の変動については一般に術後 3 時間に最高値を示すよ らであり5)，その值るはぼわれわれの成樍に近似して おり，特に本法の成績が劣っているとは考えられない： つぎに，左心室機能の推移であるが, V pm, max dp/ dt の正常值はそれぞれ4.5 $\mathrm{sec}^{-1}$ 以上, 平均 $1000 \mathrm{mmHg}$. $\sec ^{-1}$ とされている.われわれの成績では, V pm 值は斎 前値において低値を示しているが，これは湘定方法に 問題があると考えられる。しかし，V pm は心筋保荄奻

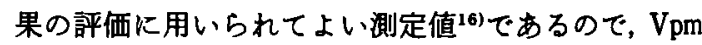
において有意の推移が認められなかったことは，本法 が有効な心筋保護法であるといえるであろう．現在ま でわれわれは心筋保護法として本法を含めて 4 方法を 行った。 そのらちの持続冠潅流法は症例が少ないので 除き，残り 3 方法での心筋保護法の成績を特に大動后 弁置換術について検討した，本法の成績はShumway の方法のそれと同じごとくであるが，症例に差がある と考えられるので，これらの成績の比較は参考程度に とどめたい，今後る本法施行による開心衍を行い，さ らに検討を加える万針である。

\section{V. 結 語}

（1）実験により Dilazepが抗カルシウム作用を示す とともに Dilazep 前投与に Young 液潅流を併用する ことにより心筋保讙効果が認められた。 
（2）抗カルシウム剤 Diladep の術前経口投与, Young 液による心停止㧍よび心表面冷却を行い，Blood Potassium Cardioplegia の間歇的冠潅流を追加する 心筋保護法は臨床面でもはぼ满足すべき成績を得た。

\section{文献}

1) Shumway, N.E. and Lower, R.R.: Topical cardiac hypothermia for extended periods of anoxic arrest. Surg. Forum, 10:563, 1960.

2) Shida, H., Kobayashi, M. and Chiba, S. : Effect of dilazep on myocardial contractility following acute ischemia and reperfusion in isolated blood-perfused canine left ventricular muscle. Jpn. Heart J., 22 : 665, 1981.

3) Chiba, S.: Effect of verapamil on frequency. force relationship in isolated dog left ventricular muscle. Jpn. J. Pharmacol., 27 : 175, 1977.

4) Lang, T.W., Corday, E., Gold, H., et al. : Consequences of reperfusion after coronary occlusion. Effects on hemodynamic and regional myocardial metabolic function. Am. J. Cardiol., $33: 69,1974$.

5) Lie, J.T., Lawrie, G.M., Morris, G.C. Jr., ET AL. : Hemorrhagic myocardial infarction associated with aortocoronary bypass revascularization. Am. Heart J., 96 : 295, 1978.

6) Jennings, R.B. and Ganote, C.E. : Structural changes in myocardium during acute ischemia. Circulat. Res., 35(Suppl. 3) : 156, 1974.

7) Clark, R.E., Ferguson, T.B., West, P.N., et al. : Pharmacological preservation of the ischemic heart. Ann. Thorac. Surg., $24: 307,1977$.

8) Lenke, D., Brock, N. and Zechel, H.J.: Zur Pharmakologie von 1,4-Bis- [3-(3,4,5-trimethoxy benzoyl-oxy)-propyl] -perhydro-1,4-diazepine (Dilazep I.N.N.), einer neuen Koronaraktiven
Substanz. Arzneim-Forsch, $22: 639,1972$.

9) Nelson, R.L., Goldstein, S.M., McConnell, D.H., et al. : Improved myocardial performance after aortic cross clampling by combining pharmacologic arrest with topical hypothermia. Circulation, 54(Suppl. 3) : III-11, 1976.

10) Melrose, D.G., Dreyer, B., Bentall, H.H., et al. : Elective cardiac arrest. Lancet, II : 21, 1955.

11) Young, W.G. Jr., Sealy, W.C., Brown, I.W. Jr., ET AL. : A method for controlled cardiac arrest as an adjunct to open-heart surgery. J. Thorac. Surg., $32: 604,1956$.

12) Follette, D.M., Steed, D.L., Foglia, R., et al. : Advantages of intermittent blood cardioplegia over intermittent ischemia during prolonged hypothermic aortic clamping. Circulation 58 (Suppl. 1) : I-200, 1978.

13 Follette, D.M., Mulder, D.G., Maloney, J.V. Jr., et al. : Advantages of blood cardioplegia over continuous coronary perfusion or intermittent ischemia. Experimental and clinical study. J. Thorac. Cardiovasc. Surg., $76:$ 604, 1978.

14) Takamoto, S., Levine, F.H., LaRaia, P.J., et al. : Comparison of single-dose and multiple-dose crystalloid and blood potassium cardioplegia during prolonged hypothermic aortic occlusion. J. Thorac. Cardiovasc. Surg., $79: 19,1980$.

15）小林裕夫, 宮内好正, 中川康次他：心筋保護を用い た体外循懪不開心術後の血清醉素变動について, Cardioplegia, 4:173, 1980.

16) Behrendt, D.M., Kirsh, M.M., Jochim, K.E., et al. : Effects of cardioplegic solution on human contractile element velocity. Ann. Thorac. Surg., $26: 499,1978$. 